\title{
SPATIO-TEMPORAL ASSESSMENT OF ENERGY CONSUMPTION AND SOCIO-ECONOMIC DRIVERS IN RURAL AREAS IN POLAND
}

\author{
Szymon Szewranski, Marian Kachniarz, Marta Sylla, \\ Malgorzata Swiader, Katarzyna Tokarczyk-Dorociak \\ Wroclaw University of Environmntal and Life Sciences, Poland \\ szymon.szewranski@upwr.edu.pl, marian.kachniarz@upwr.edu.pl, marta.sylla@upwr.edu.pl, \\ malgorzata.swiader@upwr.edu.pl, katarzyna.tokarczyk-dorociak@upwr.edu.pl
}

\begin{abstract}
The new project of the Polish Energy Policy until 2040 presents a comprehensive vision of modernization of the country's energy system. One of the directions is to develop a diffused energy system based on energy clusters at the local and sub-regional scale. Clusters are expected to increase renewable energy production and consumption mainly in rural areas, as well as improve the quality of life of local communities and ensure sustainable livelihood. Effective delineation and strategic management of energy clusters should be based on evidence-based analyses. Therefore, the aim of the paper is to assess the spatial and temporal diversification of energy use in Poland in connection to socio-economic drivers from 2004 (Polish access to the European Union) to 2017. The 314 poviat units (county) are examined (NUTS 4 level). Multidimensional data exploration and geovisualisations are performed with use of an innovative location intelligence system of combined geographical information systems (GIS) and business intelligence (BI) software. The paper presents the multivariable data analysis and mapping of selected indicators of: (1) consumption of low-voltage electricity per capita in rural households, (2) population by age and (3) place of residence, (4) residential buildings development, and (5) economic growth reflected in personal income taxes. The obtained results support regional policy makers in energy clusters' location and their strategic management. The results of the study can be used to mitigate disproportions between regions affected by unsustainable suburbanisation, depopulation and ageing society, continuous growth of energy consumption as well as economic inequalities. The study was carried out at the beginning of 2019 as an input for public discussion on ongoing works on the project of the Polish Energy Policy until 2040.
\end{abstract}

Keywords: energy clusters, rural areas, location intelligence.

\section{Introduction}

Global declarations, regional strategies, and national policies indicate that we are at the threshold of a new era in the energy sector [1]. It is foreseen that fossil fuel extraction may be limited in the next 15 years [2]. Changing the electricity market requires a new approach to energy policy. Traditional energy management systems need to be enhanced by new non-centralized production and distribution models [3]. Designed systems should have the capacity to mitigate negative trends of increasing energy costs and energy poverty [4]. Another challenge is adaptation to climate change of the ageing population [5-9]. Formulating strategic instruments and defining priority areas of support should be based on evidences and the policy integration principle [10;11].

At the end of 2018 the Polish government adopted the draft of "Energy Policy of Poland until 2040". The strategic document establishes short-term goals, such as the development of renewable energy sources (RES) in rural areas and the least developed regions. As Poland declares reaching a $21 \%$ share of renewable energy in the final energy consumption in 2030, such actions need to be implemented. The strategy states literally that in order to use the RES potential in a manner which is safe for the system, energy clusters and energy cooperatives (poviat or 5 municipalities) will be created, which should ensure balancing at the local level, by linking various technologies to energy storage capacities. Individual use of renewable energy sources should also be accompanied by energy storage [12].

Rural areas in Poland, similarly to cities, develop under strong anthropopressure [13]. The main environmental problems include water and sewage management [14], air pollution caused by heating houses [15], waste utilisation [16], soil and land protection [17-20]. At the same time, rural space is recognized as an important component of the renewable energy scheme [21]. The energetic potential depends on natural resources as well as on local infrastructure and the economic potential [22], which are influenced by the proximity of large cities [23-25]. Per capita income is recognised to have a statistically significant impact on the total number of RES [26]. 
Implementation of environmental and energy policies requires the integration of cross-sectoral activities [27]. Land ownership and structural changes in rural areas are subject to free market rules [28]. Local development involves many stake holders [29]. In this situation it is necessary to counteract social conflicts related to spatial and landscape management [30;31]. This challenge requires the development of socio-environmental and socio-energy decision support systems [32;33]. Locally-oriented decision-making models are based on different approaches, such as artificial neural networks [34;35], cellular automata [36] random forest [37], satellite imagery assessment [38], terrestrial laser scanning [39] or probabilistic modelling [40]. Another approach is the GIS-based location modelling [41-43], which is a combination of the geoscience and computational tools and can effectively support the sustainable planning process [44;45].

\section{The aim, materials and methods}

The aim of this work is to assess the spatio-temporal relationship between the diversification of energy consumption and socio-economic characteristics to support regional policy makers in energy clusters' location and their strategic management. The study examines the interplay between emerging social phenomena like aging society, energy poverty, urban sprawl, together with spatially-related changing energy demands. The paper presents a multidimensional data analysis, k-mean geographical clustering and mapping of selected indicators: (1) low voltage electricity consumption per capita in rural households, (2) population by age and (3) place of residence, (4) housing development, and (5) economic growth reflected in taxes on personal income. All 314 rural poviats in Poland are subject to analysis (the European Union's NUTS 4 level). The time dimension concerns the period after Poland's accession to the European Union (2004-2017). This is a time of dynamic changes and polarization of development processes. Multidimensional data mining and geovisualizations are carried out using an innovative system of location intelligence of connected geographical information systems (GIS) and Business Intelligence (BI) software (Figure 1). Namely, we combined ArcGIS and Tableau platforms [46;47].

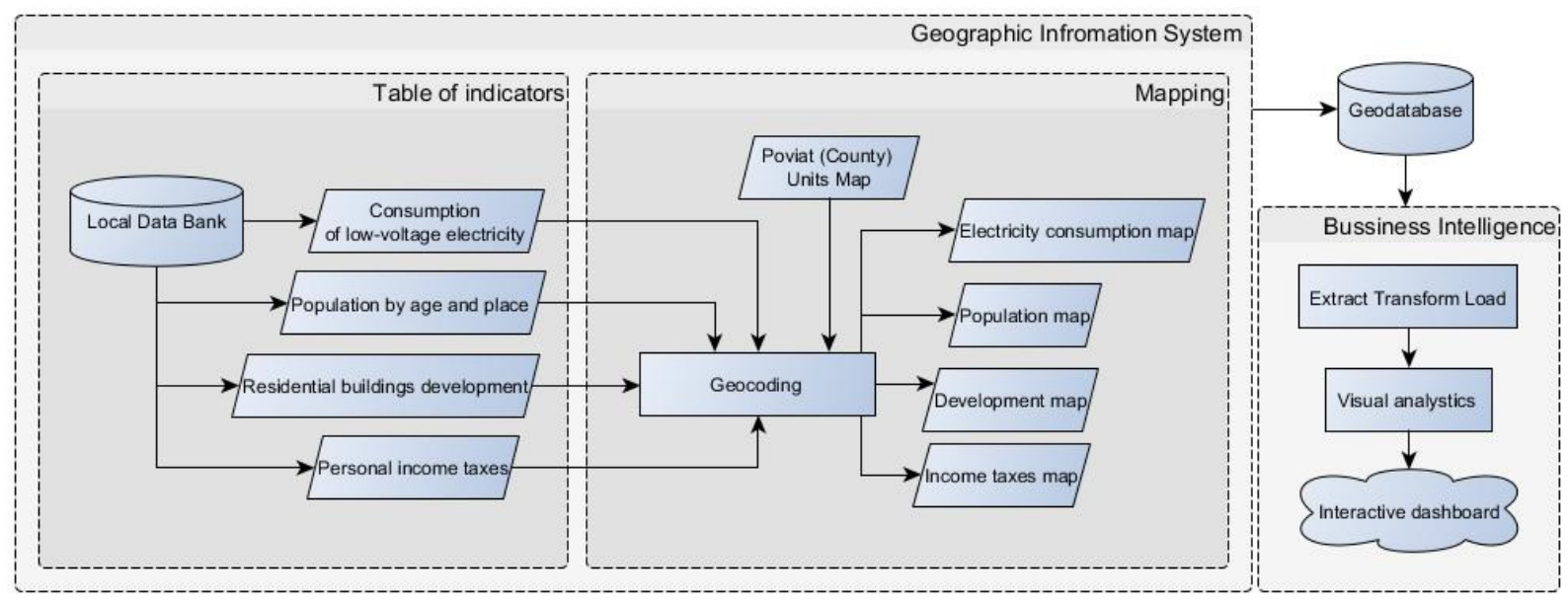

Fig. 1. Analytical framework of location intelligence system

Raw data were extracted from the Local Data Bank provided by the Statistics Poland (www.bdl.stat.gov.pl). The map of administrative divisions of Poland was acquired from repository at www.gugik.gov.pl.

\section{Results and discussion}

During the years 2004-2017 the average annual low voltage electricity consumption in rural households increased from 421 to $785 \mathrm{kWh}$ per capita. In 2004 the electricity consumption varied from 48 up to $1458 \mathrm{kWh}$ per capita. In 2017 the minimum value reached $462 \mathrm{kWh}$ per capita, while the maximum one was $1450 \mathrm{kWh}$ per capita. The averaged data do not reflect the spatial variation of energy consumption. The most significant change in electricity consumption per person occurred in eastern Poland (Figure 2), where in some poviats the growth was tenfold. The maximum relative change was fourteen times the minimum level. Cases where unit energy consumption decreased occurred only in 3 poviats. 


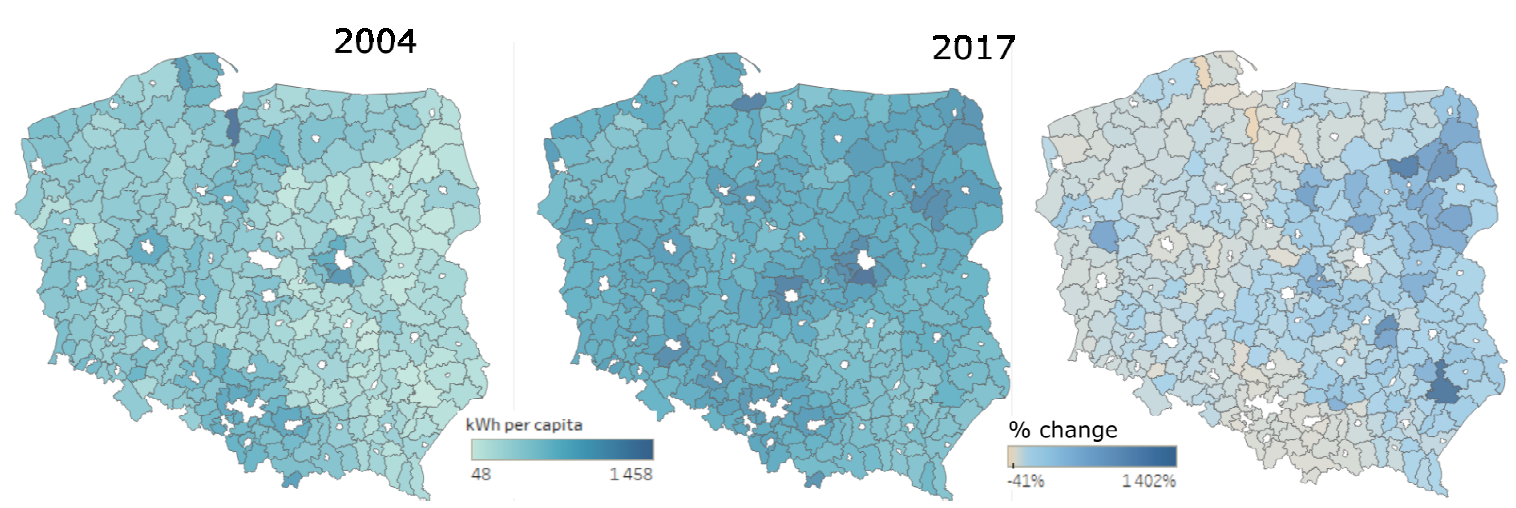

Fig. 2. Average annual low voltage electricity consumption per capita in rural households in 2004-2017 and its relative change

The average population densities in rural districts in the years 2004-2017 is analysed to explain the changes in energy consumption per capita. The negative phenomena of depopulation of rural areas (Fig. 3) far from urban centres are noticeable. At the same time, there is a significant inflow of people into rural areas adjacent to large cities. Relative population growth in the area of Warsaw, Kraków, Wrocław, Poznań or Gdańsk-Gdynia is in the range of 40-60 \%.
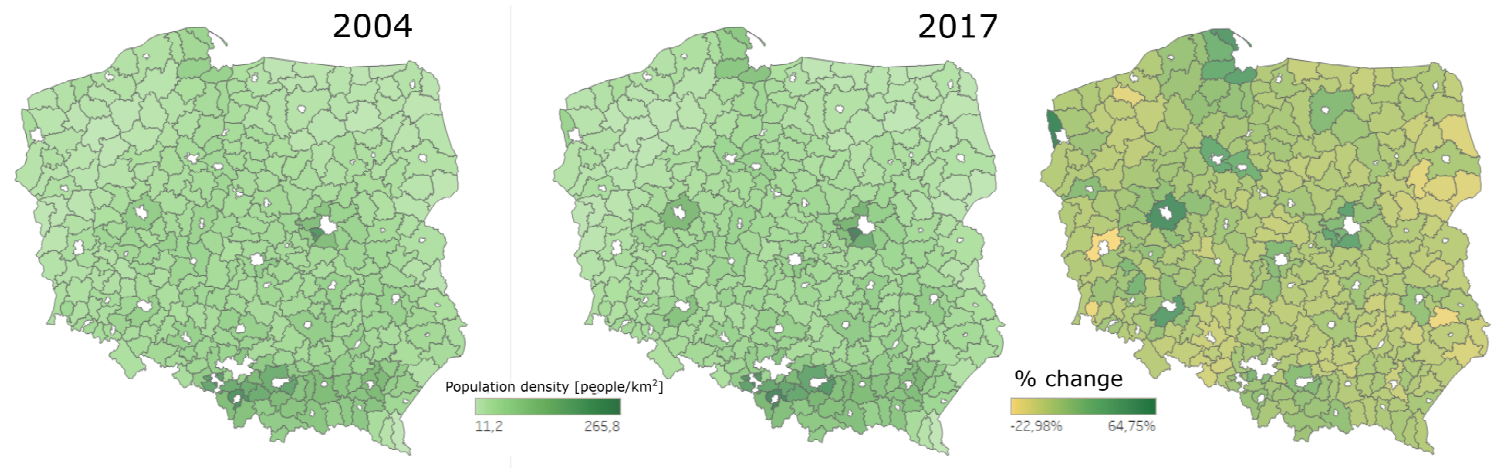

Fig. 3. Population in rural areas in Poland in 2004-2017 and its relative change

The share of population over 65 years of age as well as changes of housing resources in rural areas and local personal income taxes are also considered in the analysis (Fig.4). The phenomenon of ageing population is particularly visible in eastern and central Poland. The submountainous regions of the Sudety and Western Pomerania are also ageing. The dynamics of housing stock in rural areas show minor negative trends, but mainly major positive change in housing stock in Poland. Most significant, i.e. twofold, increase in the number of flats occurs in poviats adjacent to large cities (Fig.4.B). These are places of dynamic spread of built-up areas and at the same time the centres of economic development. Economic wealth is characterised by large disproportions in the country. Peripheral areas are several times poorer than the richest poviats (Fig.4 C).
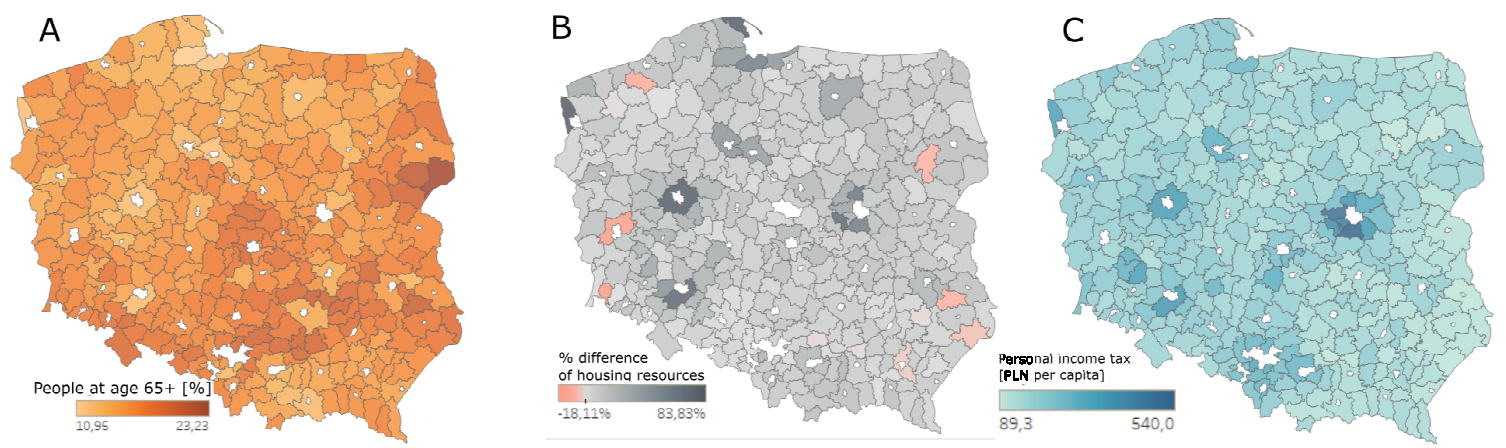

Fig. 4. Population $65+(\mathrm{A})$, changes of housing resources in rural areas (B), local personal income taxes $(C)$ 
An integrated assessment of energy consumption, demographic phenomena, poverty risk as well as development processes is conducted. Location intelligence system allows to provide interactive data explorations and multidimensional visual analytics. We conducted cluster assessment and geospatial visualisation for five indicator sets (Fig. 5).

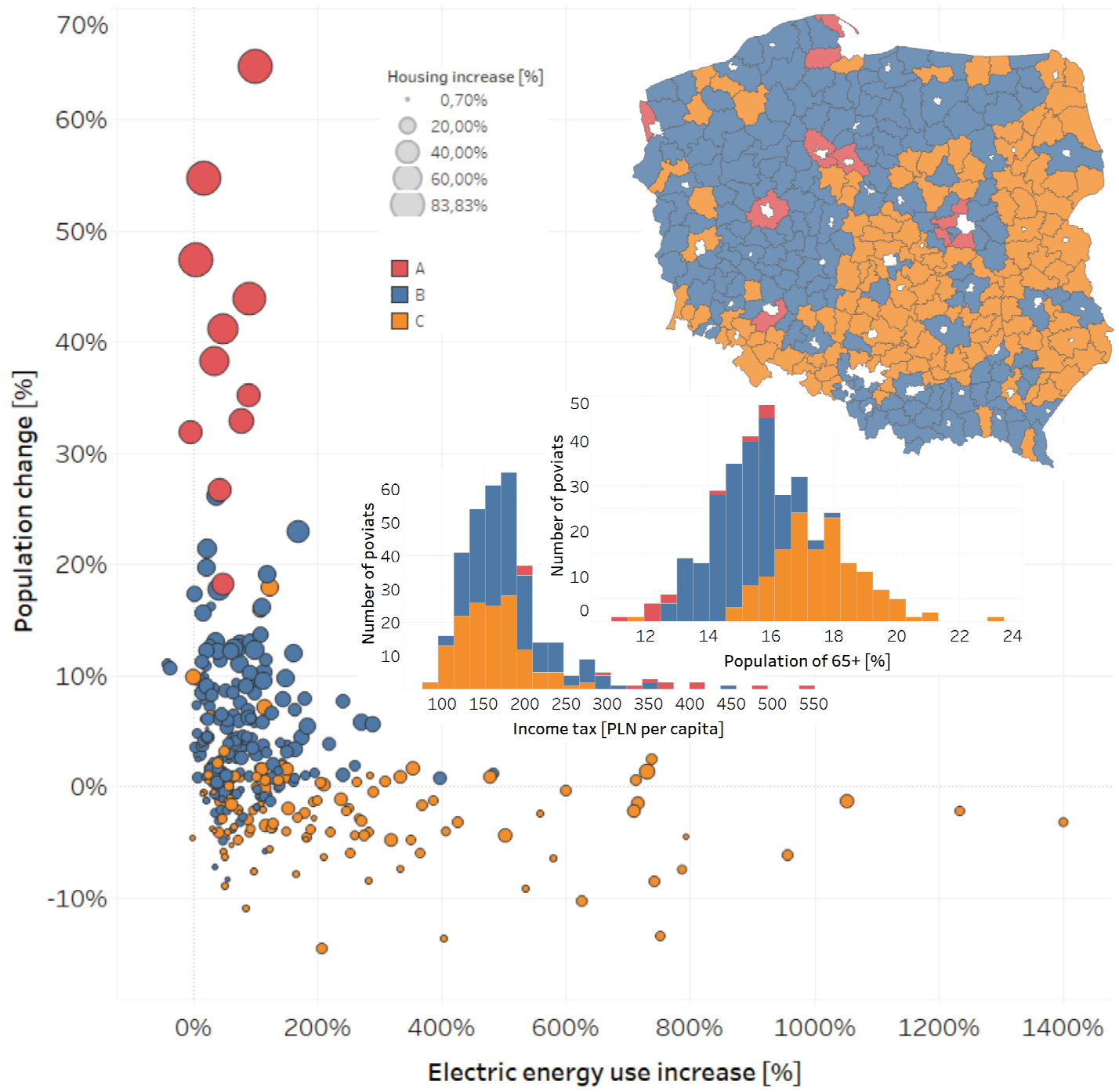

Fig. 5. Multidimensional clustering of rural areas in Poland

The results of the clustering analysis show 3 main poviat clusters (A, B, C). Group A includes districts subject to strong suburbanisation. These are areas adjacent to the largest Polish cities, such as Warsaw, Wrocław, Poznań, Gdańsk. In these areas there is a significant gain in the number of inhabitants and an expansion of housing, which means a global increase in energy consumption. At the same time, these areas are inhabited by relatively young people with the highest incomes. The global increase in the energy demand here will require new sources of production. Group B is an intermediate area. Both changes in energy consumption and economic processes remain at average level. The demographic structure is sustainable. Group $\mathrm{C}$ identifies poviats, where the population is decreasing and the number of older people with low incomes is increasing. These areas seem to be at risk of energy poverty, and it is advisable for public intervention to be targeted at these places. The intervention should include promotion of prosumer energy, based on networks of independent investors [48-50]. New paradigm based on energy cloud or a customer-oriented network can be introduced in a form of an energy cluster. They can become an efficient complementary element to the existing system, contributing to about $30 \%$ of the final electricity market in Poland. The economic benefits of the energy clusters stimulate the local economy, particularly in less urbanized areas. Poland is in the phase of constructing its long-term energy policy. One of the declared directions of activities is the development of a dispersed energy system, balanced in the local network by energy clusters. 


\section{Conclusions}

This paper presents the spatio-temporal relationship between the level of socio-economic development at the local level and the consumption of electricity assessed with the use of an innovative system of location intelligence of connected geographical information systems (GIS) and Business Intelligence (BI) software. The clustering analysis identified 3 groups of poviats: suburban cluster, middle cluster and the cluster of poviats being at risk of energy poverty. The presented decision support tool can assist decision makers in the identification of areas requiring specific forms of intervention, as well as assessment of the suitability of energy clusters to local conditions and types of energy policy. It could support integrated development policy implementation taking into account disproportions between rural areas including unsustainable suburbanization, depopulation and aging of society, increase in energy consumption and economic inequalities.

\section{Acknowledgements}

Szymon Szewrański is corresponding author; the subsequent names are given in alphabetical order.

\section{References}

[1] Jacobson M. Z., Delucchi M. A., Bauer Z. A. F. etc. Supplemental Information $100 \%$ Clean and Renewable Wind, Water and Sunlight All-Sector Energy Roadmaps for 139 Countries of the World, Joule, vol. 1, 2017, pp. 1-14.

[2] Popczyk J. Przełom w Energetyce (A breakthrough in power industry). Biblioteka Źródłowa Energetyki Prosumenckiej, 2017. 29 p.

[3] Świader M., Tokarczyk-Dorociak K., Szewrański S. etc. Analysis of regional operational programmes for the 2014-2020 period in the context of financing the renewable energy investments. Rynek Energii, vol. 124, No. 3, 2016, pp. 72-80.

[4] Ürge-Vorsatz D., Tirado Herrero S. Building synergies between climate change mitigation and energy poverty alleviation. Energy Policy, vol. 49, 2012, pp. 83-90.

[5] van Hoof J., Kazak J. K., Perek-Białas J. M. etc. The challenges of urban ageing: Making cities age-friendly in Europe. International Journal of Environmental Research and Public Health, vol. 15, No. 11, 2018. 2473.

[6] Boerenfijn P., Kazak J. K., Schellen L. etc. A multi-case study of innovations in energy performance of social housing for older adults in the Netherlands. Energy and Buildings, vol. 158, 2018, pp. 1762-1769.

[7] van Hoof J., and Kazak J. K. Urban Ageing. Indoor and Built Environment, vol. 27, No. 5, 2018, pp. 583-586.

[8] van Hoof J., Bennetts H., Hansen A. etc. The Living Environment and Thermal Behaviours of Older South Australians: A Multi-Focus Group Study. International Journal of Environmental Research and Public Health, vol. 16, No. 6, 2019, 935.

[9] van Hoof J., Schellen L., Soebarto,V. etc. Ten questions concerning thermal comfort and ageing. Building and Environment, vol. 120, 2017, pp. 123-33.

[10] Jaegersberg G., Ure J. Are We Missing Something? How Can Cluster Policies Create the Conditions for Value Generation? Renewable Energy Clusters: Recurring Barriers to Cluster Development in Eleven Countries. Cham, Springer International Publishing, 2017. pp. 245-64.

[11] Poggi F., Firmino A., Amado M. SMART RURAL: A model for planning net-zero energy balance at municipal level. Energy Procedia, vol. 122, 2017, pp. 56-61.

[12] Ministry of Energy. Energy Policy of Poland until 2040, 2018. 54 p.

[13] Dąbrowska J., Dąbek P. B., Lejcuś I. A GIS based approach for the mitigation of surface runoff to a shallow lowland reservoir. Ecohydrology \& Hydrobiology, vol.18, No. 4, 2018, pp. 420-430.

[14] Obarska-Pempkowiak H., Kołecka K., Gajewska M. etc. Sustainable sewage management in rural areas. Rocznik Ochrona Środowiska, vol. 17, No. 1, 2015, pp. 585-602.

[15]Żyromski A., Biniak-Pieróg M., Burszta-Adamiak E. etc. Evaluation of relationship between air pollutant concentration and meteorological elements in winter months. Journal of Water and Land Development, vol. 22, No. 1, 2014, pp. 25-32. 
[16] Baran J. Municipal waste management in rural areas in Poland. 19th International Scientific Conference Economic Science for Rural Development 2018. Bioeconomy. Finance and Taxes. Home Economics. New Dimensions in the Development of Society, vol. 49, No. 49, 2018, pp. 17-24.

[17] Wawer R., Nowocień E. Digital Map of Water Erosion Risk in Poland: A Qualitative, VectorBased Approach. Polish Journal of Environmental Studies, vol. 16, No. 5, 2007, pp. 763-772.

[18] Solecka I., Sylla M., Świąder M. Urban Sprawl Impact on Farmland Conversion in Suburban Area of Wroclaw, Poland. IOP Conference Series: Materials Science and Engineering, vol. 245, No. 7, 2017, 072002.

[19] Tokarczyk-Dorociak K., Kazak J., Szewrański S. The Impact of a Large City on Land Use in Suburban Area - the Case of Wrocław (Poland). Journal of Ecological Engineering, vol. 19, No. 2, 2018, pp. 89-98.

[20] Szewrański S., Kazak J., Żmuda R. etc. Indicator-Based Assessment for Soil Resource Management in the Wrocław Larger Urban Zone of Poland. Polish Journal of Environmental Studies, vol. 26, No. 5, 2017, pp. 2239-2248.

[21] Woch F., Hernik J., Linke H. J. etc. Renewable Energy and Rural Autonomy: A Case Study with Generalizations. Polish Journal of Environmental Studies, vol. 26, No. 6, 2017, pp. 2823-2832.

[22] Łączak A., Bazan-Krzywoszańska A., Mrówczyńska M. etc. Renewable Energy Sources in the Lubusz Voivodship (Poland). The Present Conditions and Perspectives for Development, Civil and Environmental Engineering Reports, vol. 28, No. 2, 2019, pp. 31-67.

[23] Przybyła K., Kulczyk-Dynowska A., Kachniarz M. Quality of life in the regional capitals of Poland. Journal of Economic Issues, vol. 48, No. 1, 2014, pp. 181-96.

[24] Świąder M., Szewrański S., Kazak J. Foodshed as an Example of Preliminary Research for Conducting Environmental Carrying Capacity Analysis, Sustainability, vol. 10 (3), 2018, 882.

[25] Przybyła K., Kulczyk-Dynowska A. Transformations of Tourist Functions in Urban Areas Territorially Linked with National Parks. IOP Conference Series: Materials Science and Engineering, vol. 471, 2019, 112038.

[26] Hernik J., Rutkowska A., Noszczyk T. Correlation between selected socioeconomic variables and the number of renewable energy sources in Świętokrzyskie Voivodeship (Poland). Proceedings of “ 15th International Scientific Conference". Engineering for Rural Development, May 25-27, 2016, Jelgaval, Latvia, pp. 498-504.

[27] Bazan-Krzywoszańska A., Skiba M., Mrówczyńska M. etc. Green energy in municipal planning documents. E3S Web Conf., vol. 45, 2018, 00006.

[28] Foryś I., Putek-Szelag E. Methods of linear ordering in estimation of potential of Polish market of agricultural property. Actual Problems of Economics, vol. 151, No. 1, 2014, pp. 542-550.

[29] Furmankiewicz M., Janc K., Macken-Walsh Á. The impact of EU governance and rural development policy on the development of the third sector in rural Poland: A nation-wide analysis. Journal of Rural Studies, vol. 43, 2016, pp. 225-234.

[30] Furmankiewicz M., Potocki J., Kazak J. Land-Use Conflicts in the Sudetes, Poland. IOP Conference Series: Materials Science and Engineering, vol. 471, 2019, 092033.

[31] Solecka I., Raszka B., Krajewski P. Landscape analysis for sustainable land use policy: A case study in the municipality of Popielów, Poland. Land Use Policy, vol. 75, 2018, pp.116-126.

[32] Kazak J. K., van Hoof J. Decision support systems for a sustainable management of the indoor and built environment. Indoor and Built Environment, vol. 27, No. 10, 2018, pp. 1303-1306.

[33] Stula T., Kazak J. Spatial Absorbency Concept as a Decision Support System for Sustainable Local Development. IOP Conference Series: Materials Science and Engineering, vol. 471, 2019, 112009.

[34]Mrówczyńska M., Skiba M., Bazan-Krzywoszańska A. etc. Social and Infrastructural Conditioning of Lowering Energy Costs and Improving the Energy Efficiency of Buildings in the Context of the Local Energy Policy. Energies, vol. 11, No. 9, 2018, 2302.

[35] Bazan-Krzywoszańska A., Mrówczyńska M., Skiba M. etc. Economic conditions for the development of energy efficient civil engineering using RES in the policy of cohesion of the European Union (2014-2020). Case study: The town of Zielona Gora, Energy and Buildings, vol. 118, 2016, pp. 170-180. 
[36] Kazak J. K. The use of a decision support system for sustainable urbanization and thermal comfort in adaptation to climate change actions-the case of the Wroclaw Larger Urban Zone (Poland). Sustainability, vol. 10, No. 4, 2018, 108.

[37] Kamińska J. A. A random forest partition model for predicting NO2 concentrations from traffic flow and meteorological conditions. Science of The Total Environment, vol. 651, 2019, pp. $475-483$.

[38] Sojka M., Jaskuła J., Wrózyński R. etc. Application of sentinel-2 Satellite imagery to assessment of spatio-temporal changes in the reservoir overgrowth process - A case study: Przebędowo, West Poland. Carpathian Journal of Earth and Environmental Sciences, vol. 14, No. 1, 2019, pp. 39-50.

[39] Płuciennik M., Hełdak M., Szczepański J. etc. Application of Spatial Models in Making Location Decisions of Wind Power Plant in Poland. IOP Conference Series: Materials Science and Engineering, vol. 245, No. 7, 2017, 72016.

[40] Żyromski A., Szulczewski W., Biniak-Pieróg M. etc. The estimation of basket willow (Salix viminalis) yield - New approach. Part I: Background and statistical description. Renewable and Sustainable Energy Reviews, vol. 65, 2016, pp. 1118-1126.

[41] Kazak J., van Hoof J., Szewranski S. Challenges in the wind turbines location process in Central Europe - The use of spatial decision support systems. Renewable and Sustainable Energy Reviews, vol. 76, 2017, pp. 425-433.

[42] Kazak J. K., Świąder M. SOLIS - A Novel Decision Support Tool for the Assessment of Solar Radiation in ArcGIS. Energies, vol. 1, No. 8, 2018, 2105.

[43] Szewrański S., Chruściński J., van Hoof J. etc. A location intelligence system for the assessment of pluvial flooding risk and the identification of stormwater pollutant sources from roads in suburbanised areas. Water, vol. 10, No. 6, 2018, 746.

[44] Wang T., Kazak J., Han Q. etc. A framework for path-dependent industrial land transition analysis using vector data. European Planning Studies, 2019.

[45] Wang T., Han Q., de Vries B. A semi-automatic neighborhood rule discovery approach, Applied Geography, vol. 88, 2017, pp. 73-83.

[46] Szewrański S., Kazak J., Sylla M. etc. Spatial Data Analysis with the Use of ArcGIS and Tableau Systems. In: Ivan, I., Singleton, A., Horák, J. etc., eds. The Rise of Big Spatial Data. Cham, Springer International Publishing, 2017. pp. 337-349.

[47] Kazak J., Chalfen M., Kamińska J. etc. Geo-Dynamic Decision Support System for Urban Traffic Management. Dynamics in GIscience. Cham, Springer International Publishing, 2018, pp. 195207.

[48] Jacobson M. Z., Delucchi M. A. Providing all global energy with wind, water, and solar power, Part I: Technologies, energy resources, quantities and areas of infrastructure, and materials. Energy Policy, vol. 39, No. 3, 2011, pp. 1154-1169.

[49] Anderson K. Ethics, ecology, and the future: Art and design face the anthropocene. Leonardo, vol. 48, No. 4, 2015, pp. 338-347.

[50]Zhang C., Wu J., Zhou Y. etc. Peer-to-Peer energy trading in a Microgrid. Applied Energy, vol. 220, 2018, pp. 1-12. 